\title{
4-1989
}

\section{Graduating From High School: New Standards in the States}

University of Pennsylvania

Follow this and additional works at: https://repository.upenn.edu/cpre_policybriefs

Part of the Curriculum and Instruction Commons, Educational Methods Commons, Education Policy Commons, Higher Education Administration Commons, and the Science and Mathematics Education Commons

\section{Recommended Citation}

University of Pennsylvania. (1989). Graduating From High School: New Standards in the States. CPRE Policy Briefs.

Retrieved from https://repository.upenn.edu/cpre_policybriefs/61

This document was authored by the Consortium for Policy Research in Education, but no individual authors were identified.

View on the CPRE website.

This paper is posted at ScholarlyCommons. https://repository.upenn.edu/cpre_policybriefs/61

For more information, please contact repository@pobox.upenn.edu. 


\title{
Graduating From High School: New Standards in the States
}

\author{
Abstract \\ This brief examines attempts by states to improve public education by increasing high school course \\ requirements in 1989. According to a report published by the Center for Policy Research in Education, \\ these attempts have had mixed results. As a result of the reforms, low-and middle-achieving students are \\ taking more courses in science and math, but there are serious questions about the quality of the courses \\ themselves. This issue of CPRE Policy Briefs is based on the report which was written with assistance \\ from Paula White and Janice Patterson. \\ Disciplines \\ Curriculum and Instruction | Educational Methods | Education Policy | Higher Education Administration | \\ Science and Mathematics Education

\section{Comments} \\ This document was authored by the Consortium for Policy Research in Education, but no individual \\ authors were identified. \\ View on the CPRE website.
}




\section{Graduating from High School: New Standards in the States}

Recent attempts by states to improve public education by increasing high school course requirements have had mixed results, according to a report published by the Center for Policy Research in Education (CPRE). As a result of the reforms, low-and middle-achieving students are taking more courses in science and math, but there are serious questions about the quality of the courses themselves, says William Clune in his report, The Implementation and Effects of High School Graduation Requirements: First Steps Toward Curricular Reform. This issue of CPRE Policy Briefs is based on the report which was written with assistance from Paula White and Janice Patterson.

The latest round of education reform has focused largely on increasing student standards. States have increased standards by requiring longer school days, minimum gradepoint averages, and high school exit exams.

But the greatest level of activity so far, has been in the area of minimum course requirements. Since 1980, 45 states have either specified for the first time, or increased the total number of courses needed to graduate from high school. Forty-two states have increased course requirements in mathematics, science or both; at least 18 added language arts requirements and about half of the states increased requirements in social studies.

This move toward tougher standards was based on the theory that higher standards, or expectations, lead to higher performance. Research also shows that students learn more if they are exposed to more content.

But are students actually being exposed to more and better content? Evidence from CPRE's in-depth study of the effects of education policies in six states indicates that the new course requirements resulted in low - and middle-achieving students taking more classes in academic subject areas. However, the courses are at the basic, general or remedial level and do not meet the goals of a high-quality, uniform curriculum proposed by $A$ Nation at Risk and other reform reports.

\section{High School Standards in the States}

Forty-five states now specify a full complement of courses needed to graduate. States list numbers of units required in core courses, including English/language arts, social studies, mathematics, and science. All but a few include physical education and health in their required lists. Other courses frequently required include fine arts and practical arts, and increasingly, computer education. Since most states require a total number of units to graduate, which normally range between 13 and 24 , students need to take several elective units to meet the required number.

Although only five states do not have minimum requirements, districts in the other 45 states may establish their own requirements, as long as these exceed the state minimums. Therefore, local district control of high school graduation course requirements is still very much in evidence virtually everywhere.

Implementation of the new course requirements has proceeded mostly on schedule throughout the nation. A survey conducted in 1986 by the Education Commission of the States found few delays or serious problems in implementing the new requirements. In 20 states, at least some districts found a shortage of teachers to staff additional courses needed to meet new state graduation minimums. Science and mathematics teachers were the ones most often in demand, because these two areas received the most attention when the increases were adopted. ${ }^{1}$

\footnotetext{
1 Grace Belsches-Simmons, et al., "Three Areas of Educational Reform: Initial Teacher Certification, Teacher Compensation and High School Graduation Requirements," Unpublished survey, (Denver: Education Commission of the States, 1987).
} 
The survey also found that although a number of state policymakers thought that districts might need additional teachers, materials or facilities in order to meet the new requirements, in most states special financial support was not given to offset increased costs. In only six states did policymakers report that new appropriations were a way to fund graduation requirements for education; but these were general increases and no funds were specifically targeted to support the new high school graduation course requirements.

It is likely that the effects of the new standards on student achievement levels will not be fully felt for several years. In many states, the new regulations did not go into effect until the class of 1987 or later. However, the Clune report provides a look at how districts and schools in some states are responding to the new requirements. The report is based on results from CPRE's continuing research on student standards and other education policies. CPRE researchers have collected information and interviewed people involved in education at state and local levels in six states-Arizona, California, Florida, Georgia, Minnesota and Pennsylvania.

\section{Course Requirements in Six States}

The purpose of CPRE's study of high school standards was to uncover the effects of recent changes in course requirements on districts and schools. The six states examined ranged in the degree of change imposed by the new legal requirements. Arizona went from 18 to 20 required credits effective in 1987; California, none (it was left up to the districts), to 13 in 1987; Georgia, 20 to 21 in 1988; and Pennsylvania, 13 to 21 credits in 1989 . Florida had no minimum requirements prior to 1983 and effective in 1989 will require 24 credits. Minnesota nominally increased requirements by adding the 9 th grade to requirements previously governing grades 10-12. In practice, Minnesota's combined 9-12 requirements have not changed in 60 years.

These criteria point to Florida as a high-change state, California as high/ moderate, Pennsylvania as moderate, Arizona and Georgia as low and Minnesota as no-change. However, changes in state requirements do not provide a complete picture of actual changes in course offerings in districts and schools. Many districts did not have to increase total credits required because they already met or exceeded state minimums. In fact, the majority of California districts already required 22 total credits to graduate (the state requires only 13 ), 75 percent of Pennsylvania districts required at least the state-mandated 21 credits, and almost all of Arizona's 226 districts already required the new state minimum of 20 units. Even without comparable district requirements, many students satisfied the new state standards in response to college or university entrance requirements.

Since researchers were interested in the effects of change, Minnesota and Georgia were eliminated from the analysis of local effects. Therefore, the findings reported below were obtained from 13 districts and 19 high schools in four states. Four of the 13 districts studied by CPRE already met or exceeded state minimums. But districts which did not have to increase total credits often had to add specific courses to meet new state requirements.

\section{Evaluating the Success of the New Student Standards}

Reformers in the six study states had two primary objectives: 1) an improvement in achievement scores and work skills; and 2) more uniformity of types of courses taken by students in the direction of standard, highquality academic courses. ${ }^{2}$ But evaluating the success of the reforms in meeting these goals is a complicated task.

In his report, Clune approaches the task of assessing the effects of the new course requirements by answering a series of questions. His answers are based on his analysis of CPRE's data and related research.

\section{Were the graduation requirements a basic success?}

\section{Clune replies:}

Yes, on their own terms. The most basic question about the success of the new graduation requirements is "were they implemented?" This question needs to be answered before any other questions about effects. It is fairly clear that the graduation re- quirements were implemented and implemented on a broad enough scale to make a difference. Of the 19 schools studied, 17 reported additions of courses or sections in math and 16 reported additions in science. CPRE's data suggest that in schools affected by the requirementsusually those with a significant number of low and middle achieversabout 27 percent of students are taking an extra math course and 34 percent an extra science course. Many are also taking a new or added course in social studies.

As a result of the new requirements, course reductions were reported in subjects such as home economics, industrial arts, physical education, vocational education, business, psychology and performing arts. Students' schedules are more filled with required courses; they are taking fewer electives.

\section{Should the states have passed even higher requirements?}

\section{Clune responds:}

Probably not. Possible criticisms of the requirements are that they were not as ambitious as they looked on paper and that they did not affect all students. It is true that large increases in the legal requirements at the state level translated into relatively small increases in practice, mostly because of pre-existing district and university requirements. In some states, the majority of districts and students were not affected at all. But the requirements were successful in changing the coursetaking of students who were taking the fewest academic courses.

In principle, the alternative of much higher graduation requirements is probably not a good idea. Requiring more academic courses on top of those already mandated (especially without other policy changes) could lead to increased concerns about the quality of courses added, pressures on student time and extracurricular activities, losses of vocational courses and electives and problems for at-risk students. Before considering further increases in graduation requirements, states with high requirements should consider redesigning

\footnotetext{
2 Lorraine M. McDonnell, "Coursework Policy in Five States and its Implications for Indicator Development," Working paper, (Santa Monica, CA: The RAND Corporation, 1988)
} 
the existing curriculum and making other policy improvements. States with relatively low requirements probably were wise to raise the minimum slowly and proceed one step at a time.

\section{Were the courses offered the most demanding possible for the students affected?}

\section{Clune Responds:}

Probably not. Given that a number of middle- and low-achieving students are taking an extra math and science course, the next most important question is the nature and quality of these courses.

As for the type of math and science courses added, sections or courses were added in general math, remedial math, consumer math, algebra, geometry and math applications. In science, sections or courses were added in general science, physical science, chemistry, physics, natural sciences, space science, earth science, general biology, laboratory science, and honors biology. But most of the additions were at the basic level. Of the 17 schools adding math sections, 15 reported additions of basic, remedial or general math. Of the 16 schools adding science sections, 14 reported additions of basic, remedial or general science.

Although no in-depth analysis of course content was conducted, there is evidence of concern about the quality of the courses. Those we interviewed in schools gave examples of reduced class time, courses with repetitious material, science "labs" in regular classrooms, misassigned teachers, and counseling of students to take weaker courses to avoid failing. We do not know how common such practices were or whether respondent perceptions would be confirmed by more in-depth analysis of content, scheduling and teacher and student assignment.

But there are deeper reasons for doubting that the new courses were the best possible. First, schools typically offer middle- and lowachieving students dull, factual and repetitive material. Second, designing the right kind of academic course for students of varying levels is very difficult. Another reason for doubting the rigor of the new courses is the lack of effort in the reform process to upgrade instruction while increasing requirements. States did not typically say "Offer an extra math class and we will help you offer the best course possible for each type of student." Graduation requirements were mandates almost totally devoid of guidance on the nature and rigor of new courses. Systematic efforts to move students from lower-level courses into higher-level ones are rare. It is unreasonable to expect that districts and schools under pressure to offer a large number of new courses in a relatively short phase-in period would simultaneously embark on a systematic program of upgrading. The opposite strategy of lowering quality to help meet the challenge is more likely.

\section{Will the reforms raise achievement scores in academic subjects?}

\section{Clune responds:}

Yes, probably a little. When students take courses with new material, their achievement scores in those subjects generally rise. ${ }^{3}$ How much they will rise, whether they will rise enough to make a difference in the workplace and whether the new skills being taught are more worthwhile than the ones they replaced cannot be answered by our data. Research has shown, however, that greater gains in achievement and income are related to more advanced, versus basic levels of instruction. ${ }^{4}$ This, together with the relatively small change in coursetaking (one or two extra basic courses) suggests quite modest gains in achievement. However, the small per student magnitude of these gains should be weighed against the extensiveness of the reform. The level of skills added to society may be substantial simply because new graduation requirements produced a small gain in a great many students.

\section{Will the reforms produce major gains in work skills?}

\section{Clune responds:}

Probably not. The theory linking traditional academic courses to work skills is quite weak and underdeveloped. The chances that existing courses would approximate those designed for maximum impact in the workplace are very small. In other words, some of the limited impact of the reform on society is due to the weakness of the theory of the reform itself. Powerful impacts on work skills may depend on radical redesign of academic education.

The precise course exchange that occurred most frequently - general math and science for vocational courses- has some disturbing potential. A Nation at Risk decried the trend away from both academic and vocational courses to the general curriculum. Recent research concludes that wages and employment of noncollege bound students benefit the most from a combination of academic and vocational courses, and lose ground economically from extra academic courses alone. The next generation of reform should consider different combinations of courses, including the option of cognitively demanding vocational education.

\section{Did the reforms increase dropout rates and hurt at-risk students?}

\section{Clune responds:}

Probably not, but there were some problems and doubts about educational quality. Many respondents in the districts CPRE visited were worried that higher standards might push students out of school but admitted that they lacked data to support their perceptions. In fact, emerging quantitative data do not support the connection. Studies have found that graduation rates are improving slightly nationwide. Furthermore, a longitudinal study of classes of students in Dade County, Florida shows a significant decline in the dropout rate over the same period that academic coursetaking was going up. In addition, other research has shown that dropping out, and its precursor, high absenteeism are in fact less prevalent in schools with high standards, provided that there is relatively little internal stratification in the educational opportunities and curricula offered to the student body (see sidebar, page 4). Ultimately, however,

\footnotetext{
3 A. Gamoran, "The Stratification of High School Leaming Opportunities," Sociology of Education 60 (1987): 135 . 155 .

4 Ibid.; C. Jencks, et al., Who Gets Aheoul? The Determinants of Economic Success in America (New York Basic Books, 1979)

5 S. Kang and J. Bishop, Vocational and Ac ademic Education in High School: Complements or Substitutes:' Working Paper 88-10 (Ithaca, NY: Center for Advanced Human Resource Studies, School of Industrial and Labor Relations. Comell University, 1988).
} 


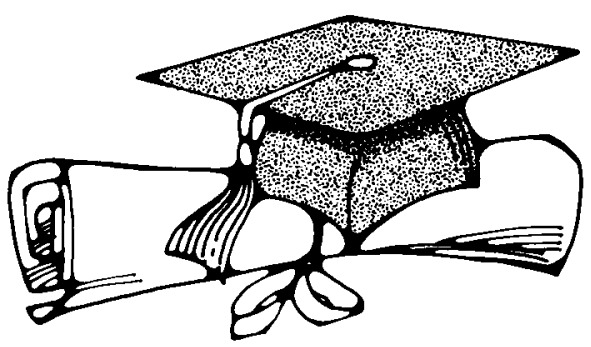

the argument over standards and dropouts must still be judged inconclusive because of lack of information.

As far as the effects of standards on the quality of education of at-risk students is concerned, the data is also inconclusive. One problem identified is the unavailability and inconvenience of remedial and makeup classes, given newly crowded schedules. When students can take makeups, a different problem is the narrowness of the curriculum. In many schools we visited, practitioners spoke of certain students taking nothing but required, remedial and makeup classes. Some students seem to take nothing but remedial classes aimed at the high school exit exam.

Another problem is watering down of the educational experience. Instead of pushing students out of school, school people seem to be bending over backwards to keep them in. While commendable, some of the rescue efforts, such as counseling students into easier courses so they can graduate instead of harder courses so they can go to college, are of questionable value.

\section{Conclusion and Recommendations}

There are elements of both success and failure in the new student standards, says Clune. The standards succeeded in getting a lot more students into basic academic courses; they failed in getting students into the most rigorous possible courses, in producing a reasonably uniform education for all students, and probably, in conveying higher-order skills necessary for a competitive economy.

Upgrading the level of instruction for all kinds of students is a long-term enterprise which requires many changes in policy. Against this more ambitious goal, the graduation requirements suffered from general deficiencies in policy design and im4 plementation.
Policy design suffered because the means and ends were not clearly related. One difficulty was the unclear relationship between academic courses and the ultimate ends of raising achievement scores and producing skills for the workplace. Math and science are reasonable guesses about what would be most useful, but what sort of math and science courses would be most useful for which purposes? What are the core skills needed in the workplace? What is the role of vocational education, if any? Curriculum decisions are difficult because of disagreement over the ends of schooling. But in making difficult choices, policymakers should push the decision one step beyond specifying course labels and decide what skills they are most interested in encouraging.

A second difficulty was the lack of attention to instruction for different kinds of students. Given the goals of raising achievement and increasing work skills, what is the best approach with students at different achievement levels? For lower-achieving students is it better to drill on the basics or focus on a core set of higher-order skills?

Ideal answers to some of these questions will require further research, but a design based on the best available knowledge would be an improvement over existing policy and help to narrow the area of indeterminacy.

The major problem of policy implementation is one that is also a problem of policy design. Schools and districts were left on their own regarding how to implement the graduation requirements. For the most part, they received little assistance in solving the many problems of designing and implementing a new program of instruction for different kinds of students. Policy design is implicated in the problems of implementation because high-quality assistance may have been impossible without clear goals.

In his report, Clune offers several suggestions for improving policy design and implementation including:

Streamline the Core Curriculum. Graduation requirements are useful policy instruments but too often they seemed to be victims of overkill. CPRE researchers saw considerable evidence of

\section{Higher Standards May Help Reduce Dropout Rates}

Higher standards for student behavior and performance can encourage student effort, discourage absenteeism and reduce the probability of dropping out, according to a study published by CPRE.

The report, The Effects of High School Organization on Oropping Out: An Exploratory Investigation, by Anthony S. Bryk and Yeow Meng Thum, is a technical analysis of a subsample of the High School and Beyond (HS\&B) database. HS\&B contains results of surveys and tests given in 1980 to students in the 10th grade. The students, both those still in school and those who had dropped out, were resurveyed two years later.

Bryk and Thum found that dropping out and the biggest predictor of dropping out-absenteeism, were less trequent in smaller schools where:

- there is an emphasis on academic pursuits;

- more commonality in the programs taken by students;

- a committed faculty; and

- an orderly environment.

excessive and cluttered requirements and the need to focus more attention on the core curriculum. High levels of non-specific credit requirements do not guarantee useful educational content, interfere with valuable extracurricular activities and may result in reduction of student effort. On the other hand, certain highly specific requirements may drive the curriculum in that area toward the lowest common denominator. Beyond a minimum level of core academic requirements, states should seriously consider whether districts and schools can make better decisions about the number and content of additional courses.

Aim the Curriculum at Higher Learning Objectives. The case for a streamlined core curriculum is strengthened because of the tendency of extra requirements to distract from the much more important and difficult question of the content of the core curriculum. To reach the educational content of courses, it is necessary to go beyond general course labels and categories (like "Mathematics") and focus on learning objectives.

A curriculum alignment move- 
ment underway in many states and localities does focus on learning objectives and high school exit exams are organized around test objectives. But these policy instruments have serious flaws. The objectives of alignment are frustrated by the many different kinds and levels of courses offered in a particular subject. And while the content of each course is regulated, there is no common core curriculum guaranteeing a quality education for all students. Some kinds of aligned curriculum, and certainly the typical high school exit exam, emphasize lower- rather than higher-order skills.

One practical step is to borrow from states like California which are taking the lead in developing higher-order learning objectives and corresponding standardized tests.

Subject-matter experts in the schools and the universities have made significant progress toward specifying the elements of a core curriculum, built around higherorder learning objectives in their fields. For example, the National Council of Teachers of Mathematics has recommended curriculum and evaluation standards aimed at enhancing mathematical problem solving, communication, and reasoning and improving the value students accord to math and the confidence with which they approach it. Similar efforts in science suggest ways of improving content, time allocated to science, sequencing of core topics and instruction. CPRE has published two reports dealing with these issues (see sidebar on page 5). Policymakers in a number of states and districts are drawing from such efforts to identify a core curriculum appropriate for their needs.

- Pay Special Attention to Instruction for Middle- and Low-Achieving Students. A difficult but important task is to develop a demanding core curriculum which emphasizes higherorder skills for low- and middleachieving students. Policymakers should design a systematic approach to the problem of remediation for students at widely differing levels of initial learning. Ways must be found to identify the most important part of the core curriculum (the core of the core, so

Changing Curriculum:

\section{The Next Wave of Education Reform?}

Since 1980, 42 states have increased high school course requirements in math, science or both. But these mandates alone are unlikely to improve the quality of math and science education, according to two reports published by CPRE. The new standardscourse requirements, minimum competency tests, etc - are likely to perpetuate curricula that are themselves outdated and ineffective, according the reports

If changes are not made in the math curric. ulum, "we will still be training a nation of shopkeepers," says Thomas Romberg. Instead of focusing on procedural skills, mathematics instruction should emphasize conceptual understanding. "All students should be taught to reason, design models, and create and solve problems, he says. "Strategies for teaching mathematics by first teaching skills and then exposing students to stylized application problems need to be reversed, knowledge should emerge from experience with problems. In his paper, Changes in School Mathematics. Curricular Changes, Instructional Changes

to speak) and to make sure that students reach at least that level. States, districts and schools need to design workable paths from remedial and weak courses to more demanding ones.

Use Different Policy Instruments for Different Purposes. Policymakers should think of multiple policy instruments in light of how they affect different groups of students. Lower-achieving students are affected by policies such as minimum graduation requirements because these are the students below the minimum. Academically oriented students are most affected by university entrance requirements, traditional conceptions of academic subjects and the structure of advanced placement exams. And some evidence suggests that the coursetaking and achievement of so-called middle students are most strongly affected by changes in the entrance requirements of the lower rung of state universities.

Different kinds of achievement tests also affect different groups of students. High school exit exams control the content of courses for lower-achieving students preparing for such exams. Advanced Placement exams affect AP courses. and Indicators of Changes, Romberg discusses curriculum and evaluation standards proposed by the National Council of Teachers of Mathematics (NCTM), He also discusses the problems of implementing and evaluating a new math curriculum.

Senta Raizen echoes concerns about current curricula in her report, Increasing Educational Productivity through Improving the Science Curriculum. A "rethinking of all aspects of the science curriculum is necessan, she says. Raizen describes the varlous elements of the science curriculum, suggesting how elements such as time, topic and course sequence, content and instructional strategies can be altered to offer the best possible science education for all students. Elementary school science instruction should tocus on a sequence of core topics that build on students own experiences and environment, Raizen argues. Instead of the current stand-alone science courses offered in secondary school, there should be a parallel progression of courses in the life and physical sciences that build on the previous year's learning. Furthermore, hands-on experiences in elementary school and laboratory investigations in secondary school are indispensable parts of science instruction.
Thus, the idea of a "uniform standard" affecting everyone in the same way is not realistic. Policymakers should be aware that different groups of students are affected by different combinations of policy instruments in different ways. It follows that those designing policies should first develop an accurate picture of the kind of students and schools that will most be affected by groups of policies and then create the policies to fit those needs.

Design Technical Assistance to Schools for Improved Content. States should provide technical assistance that recognizes and supports the potential of schools and districts to design programs that best meet the needs of their own student bodies.

- Build an Indicator System to Track Content and CourseRelated Achievement. Policymakers should consider designing and implementing indicator systems that track changes in shortterm and long-term goals (for example, coursetaking, course content and specified kinds of achievement). They should also consider a design that is sensitive to outcomes after high school (e.g., selected tracking of students). 
Continue Research on Curriculum Improvement. More basic research should be conducted to address questions such as: What are the core skills of a skilled worker which can be imparted by schooling and which kinds of courses are the best to accomplish this? What are the best methods of teaching higher-order skills to low-achieving students? How can the elementary and high school curricula be redesigned to reach the highest level of skills possible for all students?

Evaluate Changes in the Policymaking Process. The development of a long-range, multipart strategy for school improvement assumes continuity of educational planning over cycles of political elections and popularity of issues. It also requires adequate data and data analysis. In other words, what may be needed is a marriage of stable political influence and sophisticated technical capacity.

Research can say that there is plenty of room and need for improvement, and that considerable improvement seems feasible, Clune notes. However, he adds, the larger society must decide whether the task is worth the effort. Our sense as researchers is that the first wave of reform barely began an important enterprise that is well worth pursuing. Graduation requirements can be seen as a first step toward more extensive curricular improvement in secondary education.
CPRE

Management

\section{Director}

\section{Susan H. Fuhrman}

Eagleton Institute of Politics

Rutgers, The State University

of New Jersey

\section{Management Committee}

William $\mathrm{H}$. Clune

Wisconsin Center for

Education Research

University of Wisconsin-Madison

Richard F. Elmore

College of Education

Michigan State University

Marshall S. Smith

School of Education

Stanford University

\section{Executive Board}

Robert Ray

Former Governor of lowa;

President

Life Investors, Inc.

Cedar Rapids, lowa

\section{John Brandl}

Senator

Minnesota State Senate

\section{Eugene Bardach}

Professor

Graduate School of Public Policy University of California at Berkeley

Alan Campbell

Executive Vice-President

ARA Services, Inc.

Philadelphia
Patrick Daly

Teacher

Henry Ford Community College

Detroit

Amy Gutmann

Professor

Department of Politics

Princeton University

Princeton, New Jersey

Anne Larkin

Member

Massachusetts

State Board of Education

Nancy J. Lee

Teacher

Tigard High School

Tigard, Oregon

Annette Morgan

Representative

Missouri House of Representatives

Thomas Payzant

Superintendent

San Diego

Unified School District

\section{Arlene R. Penfield}

Member, Board of Education

Rouses Point, New York

Terry Peterson

Special Assistant to the President Winthrop College

Columbia, South Carolina

Robert St. Clair

Principal

Hopkins West Junior High School

Minnetonka, Minnesota

Gerald M. Tirozzi

Commissioner of Education

State of Connecticut

\section{The Center for Policy Research in Education (CPRE)}

CPRE unites four of the nation's leading research institutions in a unique venture to improve the quality of schooling. Sponsored by the Department of Education's Office of Educational Research and Improvement, the Center conducts research on the implementation and effects of state and local education policies. By communicating its findings to policymakers, CPRE contributes to the framing of policies to improve education. Members of the CPRE consortium are: Rutgers, The State University of New Jersey; Michigan State University; Stanford University and the University of Wisconsin6 Madison.
CPRE's research activities are concentrated in five major areas:

- Curriculum and Student Standards

- Teacher Policies

- Education Indicators and Monitoring

- New Rokes and Responsibilities

- Evolution of the Reform Movement
In addition to conducting research in these areas, CPRE publishes research reports and briefs on a variety of education issues. * The Center also sponsors regional policy workshops for state and local policymakers.

For further information on CPRE, contact: Lynn McFarlane, Assistant Director for Communications, CPRE, Eagleton Institute of Politics, Rutgers, The State University of New Jersey, New Brunswick, NJ 08901; phone (201) 828)3872.

*The views expressed in CPRE publications are those of individual authors and not necessarily those of the Center, its institutional members or the U.S. Department of Education. 